\title{
Influence of body composition on the bone mass of postmenopausal women
}

\author{
Unidade de Diagnóstico e Densitometria Óssea, Departamento de Fisiologia e Biofísica do ICB-USP and \\ Departamento de Ginecologia de Obstetrícia da Santa Casa de São Paulo - São Paulo, Brazil
}

\begin{abstract}
Aims: To investigate the influence of body weight (BW), fat mass (FM) and lean mass (LM) on the bone mineral density (BMD) of several areas of the skeleton. Participants: Sixty one white postmenopausal women (50.1 \pm 4.8 years). Measurements: Measurement of BMD by dual energy $\mathrm{x}$-ray absorptiometry. The results were analyzed by linear regression and the slopes of each curve were compared. Results: The results showed that the correlations between BW, FM and LM to BMD were positive, whilst the correlations between age and years since menopause to BMD were negative. LM was the main factor that influenced BMD in almost all areas. Conclusions: FM and LM present a positive effect on BMD, although LM is the main determinant of bone mass. Moreover, higher values of LM and FM present a protective effect against the reduction of BMD combined with menopause. Therefore postmenopausal women with low BW, especially low LM, present serious risk for developing osteoporosis.
\end{abstract}

UNITERMS: Body composition. Bone mass. Bone mineral density. Postmenopause.

\section{INTRODUCTION}

$\mathrm{O}$ steoporosis is a disease characterized by reduced bone mass and deterioration of microarchitecture of bone tissue, leading to the increase of bone fragility and fracture risk ${ }^{1}$. This pathology is increasingly reaching a high percentage of the world's population, considering that its clinical presentation includes fractures, especially the Colles, proximal femur and vertebrae ${ }^{2}$. Prevention has been recognized as the best approach to this disease $^{3}$, with the skill of predicting the occurence of

\author{
Adress for correspondence: \\ Antonio C. Bianco \\ Departamento de Fisiologia e Biofísica, ICB-USP \\ Av. Prof. Lineu Prestes, 1524 \\ São Paulo/SP - Brasil - CEP 05508-900
}

osteoporosis being of the utmost importance in the selection of patients for preventive treatment ${ }^{4}$. The development of precise techniques for measuring bone mass has identified patients who present high risk for osteoporotic fractures. Furthermore, these techniques have permitted the investigation of several factors which influence bone mineral density (BMD) .

Various prospective studies have showed that the risk for fractures progrèssively and continually increases as BMD decreases $^{6-8}$. Decreased bone mass detected during aging can be the consequence of low peak bone mass reached during youth', as well as of rapid deterioration of bone mass ${ }^{10}$, or both of them. In the case of women, the decrease in bone mass basically happens due to aging, normal for both sexes, and deficiency of estrogen associated with the menopause ${ }^{11}$. Besides these two factors, bone loss seems to be influenced by several factors like race, heredity, physical activity and also body composition ${ }^{12 \cdot 14}$. However, hardly anything is known about the influence of this latter 
factor on bone loss ${ }^{15-17}$. Many studies have demonstrated that body weight is positively associated with bone mass ${ }^{18-}$ ${ }^{21}$, but nevertheless there is a certain controversy with regard to the independent effects of its main components: lean and fatty tissue. Some studies have showed that the quantity of fat is the main determinant of bone density ${ }^{21,22}$, while others consider it to be the lean tissue ${ }^{23}$. The current study aims: (i) to identify what action the components of soft, lean and fatty tissues have on the bone mass of women in the postmenopausal period, utilizing the dual energy X-ray absorptiometry method; and (ii) to evaluate the effects of body composition on the decrease in bone mass due to the menopause.

\section{PATIENTS AND METHODS}

\section{Patients}

Sixty one postmenopausal women were studied. Menopause was defined as cessation of menstruation for at least 6 months, and the climacteric period was limited to 10 years. All the women were white and presented $50.1 \pm 4.8$ years of age. No one suffered from systemic diseases or was using any medicament which could influence the bone or soft tissues. This population was recruited from among Gynecology outpatients, and all patients voluntarily agreed to participate in this study.

\section{Bone Mineral Density (BMD) measurement}

The sites where BMD was measured included total skeleton, lumbar spine, femoral neck, Ward's triangle, greater trochanter, arms, legs, pelvis and head, by means of dual energy X-ray absorptiometry (DEXA) in DPX-L equipment (Lunar Corp., Madison, WI, EUA). The Bone Mineral Content (BMC) measurement of the entire body was also utilized in our study. All the patients were examined through medium scan mode, at $7.8 \mathrm{~cm} / \mathrm{s}$; the size of the sample was $1.2 \times 1.2 \mathrm{~mm}$, at $1 / 64 \mathrm{~s}$ intervals; and a collimation source of $1.68 \mathrm{~mm}$. Our experience shows that the variation coefficient of these measurements was lower than $1.5 \%$ in all bone areas.

\section{Body Composition measurement}

The height was measured by a stadiometer and the body weight (BW) by a Filizola electronic balance. Mass measurement of soft body sections, ie lean and fatty tissues, was also obtained through DEXA. Results very similar to those obtained through this method, using weight scales and anthropometric measurements of cutaneous folds, show that it is a reliable method for determining body composition $^{24}$. This technique utilizes an $\mathrm{x}$-ray source at two levels of energy. The attenuation of these energies by the lean, fatty or bone tissues is different, which allows the mass calculation for each section. The variation coefficient of fat (FM) and lean (LM) mass measurements was lower than $3 \%$.

\section{Body composition influence on $B M D$}

We examined the influence from the absolute values of LM, FM, BW and height, as well as age and years since menopause (YSM), on BMD of different bone areas, and on BMC of the entire body. In order to minimize body size differences and identify the proportion of lean and fatty tissues and consequently its influence on BMD, we calculated fat mass (FMI) and lean mass (LMI) indexes, dividing the FM and $\mathrm{LM}$ absolute values $(\mathrm{kg})$ by the square of each patient's height (h); respectively $\mathrm{FM} / \mathrm{h}^{2}$ and $\mathrm{LM} / \mathrm{h}^{2}$. Another parameter utilized was the body mass index, BMI $\left(\mathrm{BW} / \mathrm{h}^{2}\right)$. The data were analyzed through linear regression: the absolute values and the respective anthropometric parameters indexes were plotted against the BMD of all bone areas. The slopes were compared for each site, to detect which parameter has greater influence on BMD.

Considering that the BMD is calculated by dividing the bone mineral content $(\mathrm{g})$ by skeleton area $\left(\mathrm{cm}^{2}\right)$, we observe that this measurement does not reflect a real density, since it depends on the body size, and for that reason the taller individuals present overestimated bone density ${ }^{25}$. Some researchers have suggested that the division of BMD by the patient height is the best and most convenient expression for the real bone density ${ }^{21}$. For these reasons, the all-areas $\mathrm{BMD} / \mathrm{h}$ was also utilized.

\section{Analysis of body composition influence on bone mass decrease in relation to years since menopause}

For the absolute values of FM, LM e BW and for each anthropometric index (BMI, LMI, and FMI), the total group of women was divided, utilizing the median of each parameter, into two populations: $\mathrm{P} 1$ e P2, respectively the lower and higher absolute values or indices of FM, LM or BW. The BMD measurements of different bone areas were correlated with YSM, and afterwards we did linear regressions to estimate the speed of bone mass decrease (slope - $\mathrm{g} / \mathrm{cm}^{2} /$ year). Finally, the slope of the P1 and P2 straight lines were compared in order to investigate whether the populations with lower or higher anthropometric 
Table 1

Characteristics of the population studied

\begin{tabular}{lccc}
\hline & Average \pm S.D. & Interval & Median \\
\hline Age (years) & $50.1 \pm 4.8$ & $38-62$ & 51 \\
Climacterium (years) & $3.5 \pm 3.01$ & $0.50-10$ & 2.25 \\
Height $(\mathrm{m})$ & $1.56 \pm 0.1$ & $1.44-1.7$ & 1.56 \\
Weight $(\mathrm{Kg})$ & $64.2 \pm 10.9$ & $40-93$ & 64.0 \\
BMI & $26.3 \pm 4.52$ & $18.5-38.3$ & 25.8 \\
FM $(\mathrm{kg})$ & $23.8 \pm 7.73$ & $7.0-43.0$ & 22.9 \\
FMI & $9.76 \pm 3.30$ & $2.9-19.7$ & 9.10 \\
LM (kg) & $37.4 \pm 4.07$ & $27.8-49.7$ & 37.5 \\
LMI & $15.3 \pm 1.44$ & $12.8-18.9$ & 15.2 \\
\hline
\end{tabular}

FM - fatty mass, LM - lean mass and BMI, FMI and LMI are respectively body, fatty and lean mass indices

Table 2

BMD Values and Z-score of areas studied

\begin{tabular}{lccc}
\hline BMD & Average \pm SD & Interval & Z-Score Range \\
\hline Total skeleton & $1.121 \pm 0.095$ & $0.89-1.33$ & $-2.27 \mathrm{a}-3.40$ \\
Spine (L2-4) & $1.079 \pm 0.162$ & $0.74-1.46$ & $-1.64 \mathrm{a}-3.22$ \\
Femural Neck & $0.897 \pm 0.145$ & $0.52-1.20$ & $-1.06 \mathrm{a}-2.44$ \\
Ward & $0.767 \pm 0.169$ & $0.41-1.21$ & $-1.11 \mathrm{a}-3.33$ \\
Trochanter & $0.743 \pm 0.126$ & $0.49-1.06$ & $-0.93 \mathrm{a}-0.43$ \\
Pelvis & $1.087 \pm 0.116$ & $0.84-1.31$ & - \\
Arms & $0.919 \pm 0.082$ & $0.73-1.08$ & - \\
Legs & $1.107 \pm 0.110$ & $0.86-1.36$ & - \\
Head & $2.140 \pm 0.225$ & $1.69-2.61$ & - \\
\hline
\end{tabular}

We utilized a cutoff of -2.5 standard deviations below the young adult average for osteoporosis, and standard deviation between -1 and -2.5 for osteopenia. parameters differed relating to the decrease in bone mass associated with the menopause years.

\section{RESULTS}

Table 1 shows the characteristics of the women studied in terms of variation, average and median of anthropometric parameters, as well as age and menopausal years. By utilizing a cutoff of -2.5 standard deviations below the average for young adults for osteoporosis, and standard deviation of between -1 and -2.5 for osteopenia, $26 \%$ of those women presented osteoporosis and $74 \%$ osteopenia in the spine, which corresponds to the risk for fracture in this area at this stage in the life of the majority of patients who were considered in this study ${ }^{26}$. Besides this, all the women presented osteopenia in the femoral neck. Table 2 shows the patients' densitometric characteristics. It is clear that the populational sample utilized in this study has both normal and osteoporotic women, which is typical for a population of postmenopausal women.

\section{Correlation of body composition with BMD}

As Table 3 shows, there were significant correlations between BMD and anthropometric parameters in almost all areas. However, height only has influence on BMD of the spine. The body index results (BMI, FMI and LMI) hardly differed from the results of absolute values of FM,

Table 3

Correlation index $(r)$ between BMD from several bone areas and anthropometric components

\begin{tabular}{lccccccc}
\hline BMD & FM & FMI & LM & LMI & Weight & BMI & Height \\
\hline Total Body & $0.33^{\mathrm{d}}$ & $0.35^{\mathrm{d}}$ & $0.42^{\mathrm{a}}$ & $0.41^{\mathrm{b}}$ & $0.49^{\mathrm{a}}$ & $0.45^{\mathrm{a}}$ & 0.11 \\
L2-L4 & 0.21 & 0.23 & $0.39^{\mathrm{b}}$ & 0.22 & $0.41^{\mathrm{b}}$ & $0.28^{\mathrm{b}}$ & $0.32^{\mathrm{a}}$ \\
Femural Neck & 0.21 & 0.10 & $0.38^{\mathrm{c}}$ & $0.30^{\mathrm{a}}$ & $0.30^{\mathrm{a}}$ & 0.21 & 0.18 \\
Pelvis & $0.45^{\mathrm{a}}$ & $0.50 \mathrm{a}$ & $0.49^{\mathrm{a}}$ & $0.48^{\mathrm{a}}$ & $0.63^{\mathrm{a}}$ & $0.58^{\mathrm{a}}$ & 0.13 \\
Arms & 0.23 & 0.20 & $0.51^{\mathrm{a}}$ & $0.43^{\mathrm{a}}$ & $0.41^{\mathrm{a}}$ & $0.10^{\mathrm{a}}$ & 0.23 \\
Legs & 0.22 & 0.21 & $0.37^{\mathrm{c}}$ & $0.29^{\mathrm{a}}$ & $0.38^{\mathrm{b}}$ & $0.30^{\mathrm{a}}$ & 0.19 \\
Ward & $0.26^{\mathrm{t}}$ & 0.13 & $0.36^{\mathrm{a}}$ & $0.29^{\mathrm{t}}$ & $0.31^{\mathrm{a}}$ & 0.23 & 0.17 \\
Trochanter & 0.18 & 0.16 & $0.39^{\mathrm{b}}$ & $0.36^{\mathrm{c}}$ & $0.32^{\mathrm{a}}$ & $0.27^{\prime}$ & 0.12 \\
Head & $0.27^{\mathrm{t}}$ & $0.32^{\mathrm{a}}$ & 0.25 & $0.28^{\mathrm{a}}$ & $0.37^{\mathrm{a}}$ & $0.37^{\mathrm{a}}$ & 0.01 \\
Total BMC & $0.34^{\mathrm{d}}$ & $0.39^{\mathrm{b}}$ & $0.67^{\mathrm{a}}$ & $0.46^{\mathrm{a}}$ & $0.67^{\mathrm{a}}$ & $0.49^{\mathrm{a}}$ & $0.42^{\mathrm{a}}$ \\
\hline
\end{tabular}

FM - fatty mass, LM - lean mass and BMI, FMI and LMI are respectively body, fatty and lean mass indices. The statistical values of correlations are indicated:
a $_{p<0.001}$
b $0.001<p<0.002$
$C_{0.002<p<0.005}$
d $_{0.005<p<0.01}$
$e_{0.01<p<0.02}$
$f_{0.02<p<0.05}$ 


\section{Table 4}

Correlation index $(r)$ between BMD/h from bone areas and anthropometric components

\begin{tabular}{|c|c|c|c|c|c|c|}
\hline $\mathrm{BMD} / \mathrm{h}$ & FM & FMI & LM & LMI & Weight & BMI \\
\hline Total Body & $0.38^{\mathrm{c}}$ & $0.42^{\mathrm{a}}$ & 0.19 & $0.46^{a}$ & $0.38^{b}$ & $0.51^{\mathrm{a}}$ \\
\hline L2-L4 & $0.32^{d}$ & $0.30^{\circ}$ & $0.28^{\prime}$ & $0.27^{1}$ & $0.37^{c}$ & $0.35^{\mathrm{a}}$ \\
\hline Femural Neck & 0.15 & 0.14 & $0.27^{\prime}$ & $0.34^{d}$ & 0.24 & $0.25^{\circ}$ \\
\hline Pelvis & $0.53^{a}$ & $0.56^{\mathrm{a}}$ & $0.31^{e}$ & $0.53^{\mathrm{a}}$ & $0.55^{a}$ & $0.64^{\mathrm{a}}$ \\
\hline Arms & $0.26^{t}$ & $0.28^{\prime}$ & $0.30^{\circ}$ & $0.50^{\mathrm{a}}$ & $0.32^{d}$ & $0.40^{\mathrm{a}}$ \\
\hline Legs & $0.27^{t}$ & $0.29^{\prime}$ & 0.18 & $0.35^{d}$ & $0.30^{\prime}$ & $0.38^{a}$ \\
\hline Ward & 0.17 & 0.16 & $0.27^{\prime}$ & $0.32^{\circ}$ & $0.27^{\prime}$ & $0.26^{\mathrm{a}}$ \\
\hline Trochanter & 0.19 & 0.21 & $0.28^{\prime}$ & $0.40^{\circ}$ & $0.28^{\prime}$ & $0.31^{a}$ \\
\hline Head & $0.31^{\circ}$ & $0.37^{c}$ & 0.06 & $0.32^{\circ}$ & $0.28^{4}$ & $0.42^{\mathrm{a}}$ \\
\hline
\end{tabular}

FM - fatty mass, LM - lean mass and BMI, FMI and LMI are respectively body, fatty and lean mass indices. The statistical values of correlations are indicated:
a $_{p<0.001}$
b $0.001<p<0.002$
$C_{0.002<p<0.005}$
$d_{0.005<p<0.01}$
$e_{0.01<p<0.02}$
$f_{0.02<p<0.05}$

Colo do Fêmur
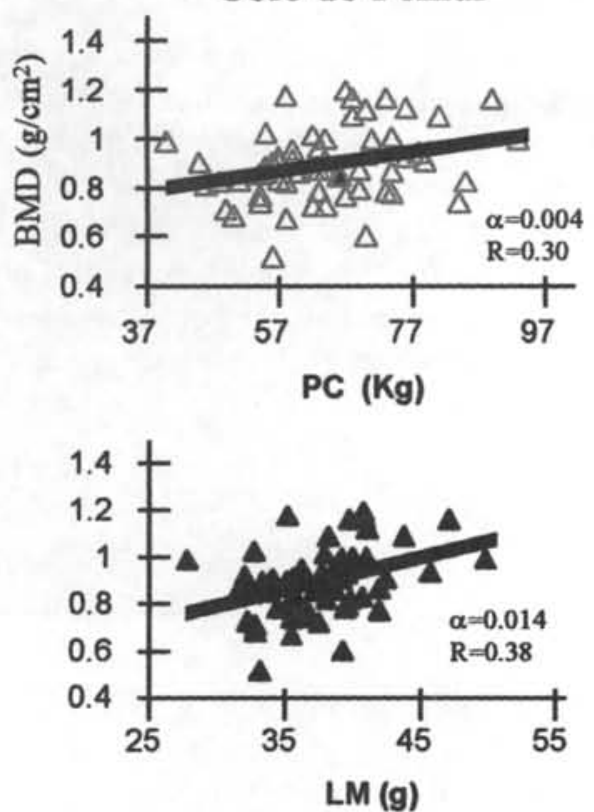

LM (g)

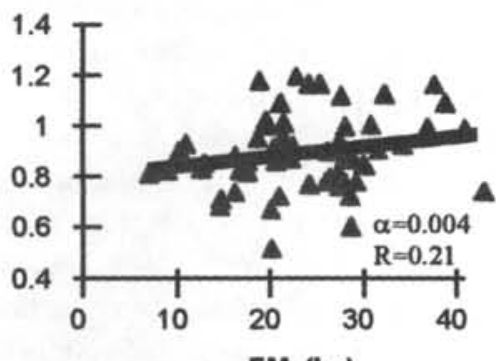

FM (kg)
LM and BW. FM positively and significantly influenced BMD of the entire body, pelvis, Ward's triangle and head, and the strongest correlation occurred for the pelvis. However, when that parameter was corrected for height (FMI), most of the correlations tended to become weaker. LM presented significant correlation with all sites analyzed, except the head, considering that the greatest correlation indices occurred in the arms and pelvis. The utilization of the lean mass index (LMI) barely modified the results, except in the spine, where the lean tissue did not affect bone mass significantly. The BMI and BW presented positive correlation with BMD in all areas, and for these two parameters the correlation was stronger in the pelvis. It is clear that the pelvis was the bone area which presented the greatest correlations with almost all parameters.

Table 4 shows that the correlation of BMD with height hardly modified the results exhibited in Table 3 , although the correlation coefficients tended to increase for FM, FMI, $\mathrm{LMI}$, and BMI, and decrease for $\mathrm{LM}$ and $\mathrm{BW}$.
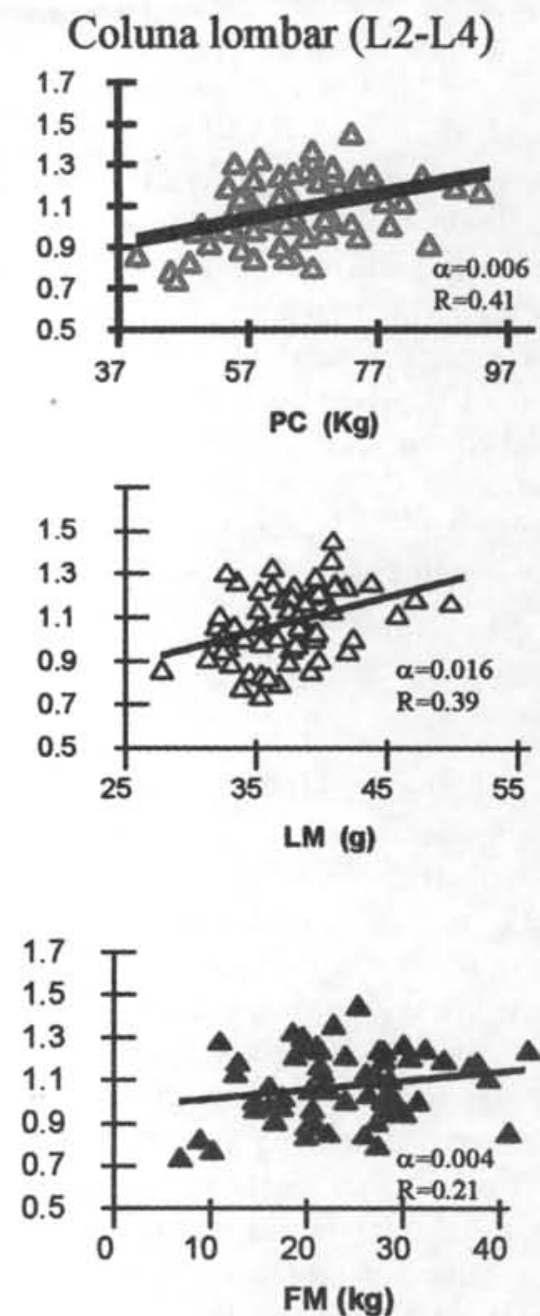

Figure 1 - Correlation of femoral BMD and spine (L2-L4) with the weight (BW), lean and fatty masses. The curves represent linear regressions from the results obtained. 
Table 5

Comparison between lean (LM) and fat masses (FM) and body weight (BW) influences on BMD of skeletal areas

\begin{tabular}{|c|c|c|c|c|c|c|}
\hline BMD (areas) & $\mathrm{LM} \times \mathrm{FM}$ & $p$ & LM $\times$ Weight & $p$ & FM $\times$ Weight & $p$ \\
\hline Total Body & $>$ & $0.05<p<0.10$ & $>$ & $0.05<p<0.10$ & $>$ & $>0.50$ \\
\hline L2-L4 & $>$ & $0.02<\mathrm{p}<0.05^{\star}$ & $>$ & $0.05<p<0.10$ & $>$ & $>0.50$ \\
\hline Femural Neck & $>$ & $0.02<\mathrm{p}<0.05^{\star}$ & $>$ & $0.02<p<0.05^{*}$ & $<$ & $>0.50$ \\
\hline Pelvis & $>$ & $0.05<p<0.10$ & $>$ & $0.02<\mathrm{p}<0.05^{\star}$ & $<$ & $>0.50$ \\
\hline Arms & $>$ & $0.002<p<0.005^{*}$ & $>$ & $0.002<p<0.005^{\star}$ & $>$ & $>0.50$ \\
\hline Legs & $>$ & $0.05<p<0.10$ & $>$ & $0.05<p<0.10$ & $>$ & $>0.50$ \\
\hline Ward & $>$ & $0.10<p<0.20$ & $>$ & $0.05<p<0.10$ & $<$ & $>0.50$ \\
\hline Trochanter & $>$ & $0.002<p<0.05^{\star}$ & $>$ & $0.02<\mathrm{p}<0.05^{*}$ & $>$ & $>0.50$ \\
\hline Head & $<$ & $0.20<p<0.50$ & $<$ & $0.20<p<0.50$ & $<$ & $>0.50$ \\
\hline Total BMC & $>$ & $<0.001^{*}$ & $>$ & $<0.001^{*}$ & $>$ & $0.20<p<0.50$ \\
\hline
\end{tabular}

The results were obtained from slope comparison for each correlation; " $p$ " represents statistical value levels.

Regarding the investigation of the anthropometric component with greatest influence on BMD, Table 5 shows that the lean tissue tended to be the most important parameter in all bone areas, except in the head. BW and FM did not present different effects to each other. Figure 1 illustrates these correlations for the femoral neck and spine. It is possible to observe that in both the femoral neck and L2$\mathrm{L} 4$, the greatest slopes occurred in the relationship between $\mathrm{LM}$ and BMD. The comparison between indices also showed that the lean tissue (LMI) is the most important parameter. However, when the same comparisons were made relating to $\mathrm{BMD} / \mathrm{h}$, the tendency for lean tissue to be the most important component remained, but did not reach the significance limit in any area of the skeleton.

\section{Influence of age and years since menopause on bone mineral density}

In all bone areas we observed lower BMD as the patients' ages increased. However, that correlation was only significant in Ward's triangle, where there was a decrease of about $1.2 \%$ per year. In other areas, bone loss ranged from 0.1 to $0.7 \%$. On the other hand, the relationship AM to BMD was significant in almost all bone areas, with the estimated rates of bone density decrease ranging from 0.6 to $2.6 \%$ per year. As can be observed in Table 6 , the speed of bone mass decrease differed between the distinct sites analyzed, with the head, Ward's triangle, spine and femoral neck being the areas which presented greater decrease in bone mass. Figure 2 demonstrates this correlation for the spine, where there was a BMD decrease of approximately 14.4 $\mathrm{mg} / \mathrm{cm}^{2}$ per year.

\section{Influence of body composition on bone mass decrease in relation to years since menopause}

Table 7 shows that women with lower FM, LM and $\mathrm{BW}$ presented greater decrease in BMD in almost all areas, when compared with those that presented higher values of these parameters. The utilization of body composition indices (BMI, FMI and LMI) led to very similar results. Regarding $\mathrm{BMC}$ of the entire skeleton, we did not find significant differences between the populations with higher or lower quantity of each anthropometric parameter (BW, FM and LM).

\section{DISCUSSION}

The results indicate the positive influence of BW on BMD of postmenopausal women, as well as its main components, lean and fatty mass. This influence continued even when we tried to minimize the scale effects through the anthropometric indices (BMI, FMI, and LMI) and BMD/ h. Furthermore, we found the lean mass to be the most important determinant of bone mineral density, which means that slimmer postmenopausal women, and especially the less muscular ones, are at greater risk of developing osteoporosis. On the other hand, we observed that the higher the values of BW and its components (FM and LM) are, the lower the estimated rate of bone loss associated with the menopause. In spite of poor knowledge of mechanisms involved in the relation of body composition to BMD during the climacteric period, we have put forward some hypotheses. 


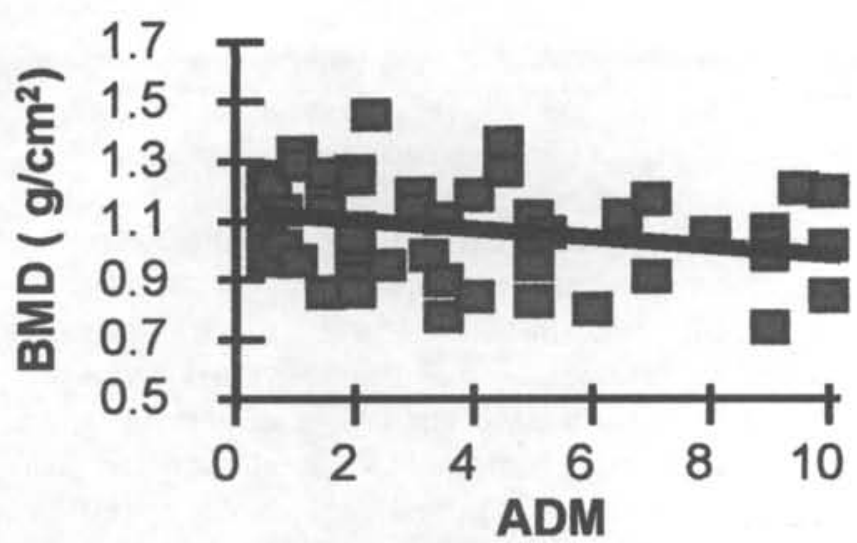

Figure 2 - Correlation of spine BMD (L2-L4) with the climacteric period. There was a bone mass decrease of approximately $14.4 \mathrm{mg} /$ $\mathrm{cm}^{2} /$ year (slope). The correlation coefficient was $0.27(0.02<\mathrm{p}<0.05)$.

\begin{tabular}{lccc}
\hline \multicolumn{5}{c}{$\begin{array}{c}\text { Table } 6 \\
\text { Correlation between BMD and menopausal years }\end{array}$} \\
\hline Areas & $\begin{array}{c}\text { Slope } \\
\left(\mathrm{mg} / \mathrm{cm}^{2} / \text { year }\right)\end{array}$ & $\mathrm{R}$ & $\mathrm{p}$ \\
\hline Total Body & -9.2 & 0.31 & $0.01<\mathrm{p}<0.02^{*}$ \\
Spine (L2-4) & -14.4 & 0.33 & $0.02<\mathrm{p}<0.05^{*}$ \\
Femural Neck & -11.4 & 0.24 & $0.05<\mathrm{p}<0.10$ \\
Ward & -20.0 & 0.35 & $0.002<\mathrm{p}<0.005^{*}$ \\
Trochanter & -7.10 & 0.17 & $0.10<\mathrm{p}<0.20$ \\
Pelvis & -8.10 & 0.21 & $0.10<\mathrm{p}<0.20^{*}$ \\
Arms & -6.0 & 0.23 & $0.05<\mathrm{p}<0.10$ \\
Legs & -9.97 & 0.27 & $0.02<\mathrm{p}<0.05^{*}$ \\
Head & -23.1 & 0.31 & $0.01<\mathrm{p}<0.02^{*}$ \\
\hline
\end{tabular}

Slope indicates the estimated speed of bone mass loss.

Referring to the lean mass, it is understood that the mechanical stress generated by muscular contraction, which results in stimulus for bone formation, is the way that this lean mass can positively interfere in the bone mass. This is evident in the case of individuals subjected to immobilization, for whom there is a large and fast decrease in bone mass ${ }^{27}$. Moreover, men present higher BMD than women, and this is partly due to men presenting higher muscular mass. In evidence for this is the fact that the difference in bone density between the sexes disappears when BMD is corrected for the muscular mass ${ }^{28,29}$. In addition, the bone loss associated with ageing is partially related to the muscular mass decrease, since the correction of BMD for the lean mass also annuls the bone loss related to age $^{30}$.

Regarding the fatty mass, one quite acceptable explanation is the greater mechanical stress resulting from the increased muscular activity for the action of supporting and/or locomotion of more corpulent women, which stimulates bone formation as already mentioned. The high production of estrone by the adipocytes from adrenal androgens in more obese women was suggested a long time ago as a factor protecting against mass loss associated with the menopause. However, recent studies have showed that the relation estrone to BMD is much less than that of fat to $\mathrm{BMD}^{22}$. Furthermore, the fact that there is equal influence of fatty mass in premenopausal women suggests that it is not the principal mechanism responsible for this correlation $^{21.22}$, especially because these women hardly depend at all on estrogen produced by the adipocytes. Another endocrine mechanism that has been suggested to explain the FM effect is the hyperinsulinemia which comes from obesity, in view of the fact that insulin has an anabolic effect on bone tissue. However, in spite of finding positive correlations between bone density and circulating insulin levels in postmenopausal women, we did not find convincing

Table 7

Comparison of bone mass reduction through the menopausal years, in populations with lower (P1) or higher (P2) FM, LM or BW

\begin{tabular}{lcccccc}
\hline BMD areas & FM & $p$ & LM & $p$ & Weight & $p$ \\
\hline Total Body & $\mathrm{P} 1>\mathrm{P} 2$ & $<0.001^{*}$ & $\mathrm{P} 1>\mathrm{P} 2$ & $<0.001^{*}$ & $\mathrm{P} 1>\mathrm{P} 2$ & $<0.001^{*}$ \\
L2-L4 & $\mathrm{P} 1>\mathrm{P} 2$ & $<0.001^{*}$ & $\mathrm{P} 1>\mathrm{P} 2$ & $<0.001^{*}$ & $\mathrm{P} 1>\mathrm{P} 2$ & $<0.001^{*}$ \\
Femural Neck & $\mathrm{P} 1<\mathrm{P} 2$ & $0.20<\mathrm{p}<0.50$ & $\mathrm{P} 1>\mathrm{P} 2$ & $0.002<\mathrm{P}<0.005^{\star}$ & $\mathrm{P} 1>\mathrm{P} 2$ & $0.02<\mathrm{p}<0.05^{*}$ \\
Ward & $\mathrm{P} 1<\mathrm{P} 2$ & $0.05<\mathrm{p}<0.10$ & $\mathrm{P} 1>\mathrm{P} 2$ & $0.002<\mathrm{p}<0.005^{*}$ & $\mathrm{P} 1>\mathrm{P} 2$ & $0.01<\mathrm{P}<0.02^{*}$ \\
Trochanter & $\mathrm{P} 1>\mathrm{P} 2$ & $<0.001^{*}$ & $\mathrm{P} 1>\mathrm{P} 2$ & $>0.50$ & $\mathrm{P} 1>\mathrm{P} 2$ & $>0.50$ \\
Pelvis & $\mathrm{P} 1>\mathrm{P} 2$ & $<0.001^{*}$ & $\mathrm{P} 1>\mathrm{P} 2$ & $<0.001^{*}$ & $\mathrm{P} 1>\mathrm{P} 2$ & $<0.001^{*}$ \\
Arms & $\mathrm{P} 1=\mathrm{P} 2$ & $>0.50$ & $\mathrm{P} 1>\mathrm{P} 2$ & $<0.001^{*}$ & $\mathrm{P} 1>\mathrm{P} 2$ & $<0.001^{*}$ \\
Legs & $\mathrm{P} 1>\mathrm{P} 2$ & $0.05^{*}$ & $\mathrm{P} 1>\mathrm{P} 2$ & $<0.001^{*}$ & $\mathrm{P} 1>\mathrm{P} 2$ & $0.10<\mathrm{p}<0.20$ \\
Head & $\mathrm{P} 1>\mathrm{P} 2$ & $0.20<\mathrm{p}<0.50^{*}$ & $\mathrm{P} 1>\mathrm{P} 2$ & $0.002<\mathrm{p}<0.005^{*}$ & $\mathrm{P} 1<\mathrm{P} 2$ & $>0.50$ \\
Total BMC & $\mathrm{P} 1>\mathrm{P} 2$ & $>0.50$ & $\mathrm{P} 1>\mathrm{P} 2$ & $>0.50$ & $\mathrm{P} 1>\mathrm{P} 2$ & $>0.50$ \\
\hline
\end{tabular}

The results were obtained from slope comparison of $\mathrm{P} 1$ vs. P2 for each bone area. 
Table 8

Correlations between body composition measurements

\begin{tabular}{lrlllll}
\hline$r$ & Height & Weight & BMI & Fat & FMI & Lean \\
\hline Weight & $0.24^{\mathrm{b}}$ & & & & & \\
BMI & -0.18 & $0.83^{\mathrm{a}}$ & & & & \\
Fat & 0.05 & $0.93^{\mathrm{a}}$ & $0.84^{\mathrm{a}}$ & & & \\
FMI & 0.17 & $0.86^{\mathrm{a}}$ & $0.94^{\mathrm{a}}$ & $0.97^{\mathrm{a}}$ & & \\
Lean & $0.49^{\mathrm{a}}$ & $0.78^{\mathrm{a}}$ & $0.58^{\mathrm{a}}$ & $0.51^{\mathrm{a}}$ & $0.40^{\mathrm{a}}$ & \\
LMI & -0.16 & $0.71^{\mathrm{a}}$ & $0.79^{\mathrm{a}}$ & $0.54^{\mathrm{a}}$ & $0.57^{\mathrm{a}}$ & $0.78^{\mathrm{a}}$ \\
\hline
\end{tabular}

The data are correlation coefficients. The significant correlations are indicated.

${ }^{\mathrm{a}} \mathrm{p}<0.001$

${ }^{\circ} 0.02<p<0.05$

evidence to establish hyperinsulinemia as the mechanism responsible for the relation fat to $\mathrm{BMD}^{31}$. Moreover, there is some genetic evidence for the relation FM to BMD, in which there would be crossed heredity of these attributes ${ }^{32,33}$.

All the same, the results found in the current study demonstrate that the mechanical stress which comes from muscular contraction is the most important determinant of bone density. Evidence of this came from the high correlation of BMD of the arms with LM, and the absence of correlation with FM. Considering that this area does not carry much weight, and it is almost continually moving, that is to say, under permanent influence from muscular activity, we think that the mechanical stress fostered by muscular contraction is the determinant factor for BMD of this area, especially because the most obese women presented the same rate of bone mass loss in the arms, when compared with the slimmest ones.

On the other hand, the head was influenced by the fat, but it was not significantly influenced by LM, as would be predicted, considering that this area has low muscular activity and obviously does not suffer weight loss. However, another interesting result was that the highest rate of bone loss, caused by the estrogen deficiency (menopause), occurs in the head $\left(\sim 23.1 \mathrm{mg} / \mathrm{cm}^{2} /\right.$ year $)$. This suggests that the lack of protective effect from mechanical stress in this site could partially explain the more accentuated loss in the head, and once again provides evidence for the importance of the muscular component on bone tissue.

Another detail that shows the lean tissue as the main determinant of bone mass was the positive and significant correlation between BMD and LM in areas that support weight, and which are affected by muscular activity, such as the femoral neck and legs; and the absence of correlation of BMD from these areas with fat mass. In addition, women with more lean mass presented less bone mass loss in these areas, whilst greater fat mass did not offer this protective effect in the femoral neck against osteopenia associated with the menopause.

With regard to the age effect and menopause years on bone mass loss, we did not find significant influence of chronological age during the first ten years of menopause. On the other hand, the decrease of BMD is strongly related to the climacteric period, especially in the head, spine (L2L4) and Ward's triangle. These results seem to show, in accordance with other transversal studies ${ }^{34}$, that age has an osteopenic effect independent of the menopausal years. All the same, considering that YSM presents a positive correlation with age, we think that the deterioration in bone mass during the climacterium is due to ageing effects in addition to the estrogen deficiency effects that come from ovarian death. However, the menopausal period was shown to be the most important determinant of bone density reduction.

In conclusion, both the fatty and lean masses positively affect BMD, but the latter component is the main determinant of bone mineral density. The climacteric period, not the ageing, is the predominant causative factor for bone mass loss during the first ten years after the menopause. However, greater quantities of lean and fatty masses have a protective effect against this reduction of BMD. These results show that slimmer women, especially those with less muscular mass, present higher risk for developing osteoporosis during the postmenopausal period. 


\section{Resumo}

Objetivo: Investigar a influência do peso corporal (PC), massa gorda (FM) e massa magra (LM) na densidade mineral óssea (BMD) de várias regiōes do esqueleto. Participantes: Sessenta e uma mulheres brancas na pós-menopausa (50.1 \pm 4.8 anos). Mensuração: Medida do BMD através da densitometria duo-energética. Os resultados foram analisados através de regressão linear e os slopes de cada curva foram comparados. Resultados: Mostraram que as correlações PC-, FM- e LM-BMD foram positivas, enquanto que as correlaçōes idade-e anos de climatério-BMD foram negativos. LM foi o principal fator que influenciou - BMD em quase todas as regiões ósseas. Conclusão: FM e LM apresentam efeito positivo no BMD, entretanto, LM é o principal determinante da massa óssea. Além do mais, maiores valores de LM e FM têm um efeito protetor na diminuição do BMD decorrente da menopausa. Portanto, mulheres no climatério com baixo PC, especialmente, baixo LM apresentam maior risco de desenvolver osteoporose.

\section{REFERENCES}

1. Consensus development conference - Profilaxis and treatment of osteoporosis. Am J Med 90:107-110, 1991.

2. Stevenson, JC; Marsh, MS. An atlas of osteoporosis - The encyclopaedia of visual medicine series. The Parthenon publishing group, USA, New Jersey, 1992.

3. Riggs, BL; Melton III, LJ. The prevention and treatment of osteoporosis. N Engl J Med 9:620-627, 1992.

4. Lindsay, R. Prevention of osteoporosis. In: Favus, M.J. Primer of the Metabolic Bone Diseases and Disorders of Mineral Metabolism. New York, Raven Press, 240-244, 1993.

5. World Health Organization. Assessment of fracture risk and its application to screening for postmenopausal osteoporosis: technical report series. WHO, Geneva, 1994.

6. Gardnell, P; Johnell, O; Nilsson, BE. The protective value of bone loss for fragility fractures in women: a longitudinal study over 15 years. Calcif Tisue Itern 49:90-94, 1991.

7. Hui, SL; Slemenda, CW; Johnson, CC. Age and bone mass as predictors of fracture in a prospective study. J Clin Invest 81:1804-1809, 1988.

8. Ross, PD; Wasnich, RD; Vogel, JM. Detection of prefracture spinal osteoporosis using bone mineral absorptiometry. J Bone Miner Res 3:1-11, 1988.

9. Ott, SM. Bone density in adolescents. N Engl J Med 325:1646-1647, 1991.

10. Hui, SL; Slemenda, C.W; Johnson, CC. The contribution of bone loss to potmenopausal osteoporosis. Osteoporosis Intern 1:30-34, 1990.

11. Stevenson, JC; Lees, B; Devenport, M; Cust, MP; Ganger, KF. Determinants of bone density in normal women: risk factors for future osteoporosis. Br Med J 298:924-928, 1989.
12. Brewer, V; Meyer, B; Keele, MS; Upton, SJ; Hagan, RD. Role of exercise in preventing involutional bone loss. Med Sci Sports Exercise 15:445-449, 1983.

13 Cohn, SH; Abesamis, C; Ymasura, S; Aloia, JF; Zansi, I; Ellis, KJ. Comparative skeletal mass and radial bone mineral content in black and white women. Metabolism 26:171-178, 1977.

14. Pocock, NA; Eisman, JA; Hopper, JL; Yeates, MG; Sambrook, PN; Ebert, S. Genetic determinants of bone mass in adults. J Clin Invest 80:706-710, 1987.

15. Harris, S; Dallal, GE; Dawson-Hughes, B. Influence of body weight on rates of change in bone density of the spine, hip, and radius in postmenopausal women. Calcif Tissue Int. 50:19-23, 1992.

16. Rigs, BL; Wahner, HW; Melton III, LJ; Richelson, LS; Judd, HL; Offord, KP. Rates of bone loss in the appendicular and axial skeletons of women. J Clin Invest 77:1187-1191, 1986.

17. Tremollieres, FA; Pouilles, JM; Ribot, C. Vertebral postmenopausal bone loss is reduced in overweight women - a longitudinal study in 155 early postmenopausal women. J Clin Endocrinol Metab 77:683-686, 1993.

18. Cundy, T; Evans, M; Robert, H; Wattie, D; Ames, R; Reid, I. Bone density in women using depot medroxyprogesterone acetate for contraception. Br Med J 303:13-16, 1991.

19. Gambacciani, M; Spinetti, A; Simone, L; Cappagli, B; Maffei, S; Taponeco, F; Fioretti, P. The relative contributions of menopause and ageing to postmenopausal vertebral osteopenia. J Clin Endocrinol Metab 77:1148-1151, 1993.

20. Nordin; BEC; Need, AG; Brigdes, A; Horowitz, M. Relative contributions of years since menopause, age, and weight to vertebral density in postmenopausal women. $\mathrm{J}$ Clin Endocrinol Metab 74:20-23, 1992. 
21. Reid, IR; Plank, LD; Evans, MC. Fat mass is an important determinant of whole body bone density in premenopausal women but not in men. J Clin Endocrinol Metab 75:45-51, 1992.

22. Reid, IR; Ames, R; Evans, MC; Sharpe, S; Gamble, G; France, JT; Lim, TMT; Cundy, TF. Determinants of total body and regional bone mineral density in normal postmenopausal women - a key role for fat mass. J Clin Endocrinol Metab 75:45-51, 1992.

23. Bevier, WC; Wiswell, RA; Pyka, G; Kozak, KC; Newhall, KM; Marcus, R. Relationship of body composition, muscle strength, and aerobic capacity to bone mineral density in older men and women. J Bone Mineral Res 4:421-32, 1989.

24. Ogle, GD; Allen, JR; Humphries, IRJ; Lu, PW; Briody, JN; Morley, K; Howman-Giles, R; Cowell, CT. Bodycomposition assessment by dual-energy $\mathrm{x}$-ray absorptiometry in subjects aged 4-26 y. Am J Clin Nutr 61:746-753, 1995.

25. Adami, S; Kanis, JA. Assessment of involutional bone loss: Methodological and conceptual problems. J Bone Miner Res 10:511-517, 1995.

26. Kanis, JA; Melton, J; Christiansen, C; Johnston, CC; Khaltaev, N. The diagnosis of osteoporosis. J Bone Miner Res 9:1137-1141, 1994.

27. Steward, AF; Adler, M; Byers, C.M; Segre, GV; Broadus, AE. Calcium homeostasis in immobilization: An example of resorptive hypercalciuria. N Engl J Med 306:1136-1140, 1982.

28. Bonjour, JP; Theintz, G; Buch, B; Slosman, D; Rizzoli, R. Critical years and stages of puberty for spinal and femoral bone mass accumulation during adolescence. J Clin Endocrinol Metab 73:555-563, 1991.

29. Buchs, B. et al. Densité minerale osseuse de la colonne lombaire, du col et de la diaphyse femoraux d'un echantillon de la population genevoise. Schweiz Med Wochenschr 122:1129-1136, 1992

30. Donaldson, LJ; Cook, A; Thompson, RG. Incidence of fractures in a geographically defined population. Journal Epidemiol Community Health 44:241-245, 1990.

31. Reid, IR; Evans, M; Cooper, GJS; Ames, RW; Stapleton, J. Circulating insulin levels are related to bone density in normal postmenopausal women. Amer Physiol Society 28:E655-E659, 1993.

32. Bouchard, C; Tremblay, A; Després, J; et al. The response to long-term overfeeding in identical twins. N Engl J Med 322:1477-1482, 1990.

33. Stunkard, AJ; Harris, JR; Pedersen, NL; McClearn, GE. The body mass index of twins who have been reared apart. $\mathrm{N}$ Engl Med 322:1483-1487, 1990.

34. Nilas, L; Christiansen, C. Bone Mass and its relationship to age and the menopause. J Clin Endocrinol Metab 65:697$702,1987$. 